Check for updates

Cite this: RSC Adv., 2019, 9, 7961

Received 12th January 2019

Accepted 2nd March 2019

DOI: $10.1039 / c 9 r a 00277 d$

rsc.li/rsc-advances

\section{Hyperpatulones A-F, polycyclic polyprenylated acylphloroglucinols from Hypericum patulum and their cytotoxic activities $\uparrow$}

\author{
Zhong-Nan Wu, ${ }^{a}$ Qian-Wen Niu, ${ }^{a}$ Yu-Bo Zhang, ${ }^{\text {ab }}$ Ding Luo, ${ }^{a}$ Qing-Guo Li, ${ }^{c}$ \\ Ying-Ying Li, ${ }^{a}$ Guang-Kai Kuang, ${ }^{a}$ Li-Jun He, ${ }^{a}$ Guo-Cai Wang (iD *ab and Yao-Lan Li*a \\ Six new compounds, hyperpatulones A-F (1-6), along with ten additional known related derivatives (7-16), \\ were isolated from Hypericum patulum (Guttiferae). Their structures were elucidated by extensive analysis of \\ spectroscopic data (IR, UV, HRESIMS, 1D and 2D NMR), X-ray crystallography, electronic circular dichroism \\ (ECD) spectroscopy and $\mathrm{Rh}_{2}\left(\mathrm{OCOCF}_{3}\right)_{4}$-induced $\mathrm{ECD}$. All compounds were tested for their cytotoxic \\ activities on human HepG-2, HeLa, MCF-7, and A549 cell lines via 3-(4,5-dimethylthiazol-2-yl)-2,5- \\ diphenyltetrazolium bromide (MTT) assay. Compound 5 exhibited significant cytotoxicities against HepG-2, \\ HeLa and A549 cell lines with $\mathrm{IC}_{50}$ values of $9.52 \pm 0.27,11.87 \pm 0.22$ and $12.63 \pm 0.12 \mu \mathrm{M}$, respectively.
}

\section{Introduction}

Hypericum patulum (Guttiferae) is well known as "Jinsimei" in China, and is distributed mainly in southwest China, such as Guizhou, Sichuan and Yunnan Provinces. ${ }^{1}$ The herbs of $H$. patulum are used as a traditional medicine to clear heat, cool blood, relax tendons and activate collaterals, and to treat gonorrhea, hepatitis, colds, etc. ${ }^{2-6}$ Modern pharmacological investigations demonstrated that the plants of the genus Hypericum possessed anti-depression, ${ }^{7-11}$ anti-tumor, ${ }^{12-18}$ anti-

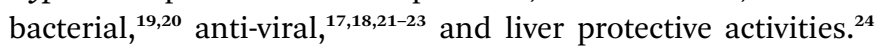
Previous phytochemical studies on these plants showed that derivatives of polycyclic polyprenylated acylphloroglucinols (PPAPs), which possessed a highly oxygenated bicyclo[3.3.1] nonane-2,4,9-trione or other related core decorated with $\mathrm{C}_{5} \mathrm{H}_{9}$ or $\mathrm{C}_{10} \mathrm{H}_{17}$ (prenyl or geranyl) side chains, were the main bioactive components. ${ }^{7,13-19,21,24,25}$

In this paper, we report the isolation and structural elucidation of six new PPAPs (1-6) (Fig. 1), together with ten known

${ }^{a}$ Institute of Traditional Chinese Medicine \& Natural Products, Guangdong Province Key Laboratory of Pharmacodynamic Constituents of TCM and New Drugs Research, College of Pharmacy, Jinan University, Guangzhou 510632, People's Republic of China.E-mail: twangguocai@jnu.edu.cn; tliyl@jnu.edu.cn

${ }^{b}$ Integrated Chinese and Western Medicine Postdoctoral Research Station, Jinan University, Guangzhou 510632, People's Republic of China

${ }^{c}$ School of Pharmaceutical Sciences, Guangzhou University of Chinese Medicine, Guangzhou 510006, China

$\dagger$ Electronic supplementary information (ESI) available: ECD spectra of the $\left[\mathrm{Rh}_{2}\left(\mathrm{OCOCF}_{3}\right)_{4}\right]$ complexes of compounds 1-4 with the intrinsic ECD spectrum subtracted, calculated and experimental ECD spectra of 1-6, detailed HRESIMS, UV, IR, 1D, 2D NMR data of compounds 1-6. CCDC 1865373. For ESI and crystallographic data in CIF or other electronic format see DOI: 10.1039/c9ra00277d ones (7-16). Their structures were elucidated using spectroscopic data, X-ray crystallography, ECD spectroscopy and $\mathrm{Rh}_{2}(-$ $\left.\mathrm{OCOCF}_{3}\right)_{4}$-induced ECD. Moreover, compounds 1-16 were evaluated for their cytotoxic activities on human HepG-2, HeLa, MCF-7, and A549 cell lines using the MTT assay. Among them, compound 5 shows significant cytotoxicities toward HepG-2, HeLa and $\mathrm{A} 549$ cell lines $\left(\mathrm{IC}_{50}=9.52 \pm 0.27,11.87 \pm 0.22\right.$ and $12.63 \pm 0.12 \mu \mathrm{M})$.

\section{Results and discussion}

The 95\% EtOH extract of Hypericum patulum was subjected to liquid-liquid fractionation to afford a petroleum ether (PE)soluble fraction and an ethyl acetate (EtOAc)-soluble fraction. The PE fraction was separated by silica gel column chromatography, Sephadex LH-20 and preparative HPLC to obtain six new compounds (1-6) and ten known ones (7-16).

Compound 1 was isolated from $\mathrm{CH}_{3} \mathrm{OH}$ as colorless crystals with $[\alpha]_{\mathrm{D}}^{25}+39.6(c$ 1.0, $\mathrm{MeOH})$. Its molecular formula was deduced as $\mathrm{C}_{38} \mathrm{H}_{50} \mathrm{O}_{6}$ on the basis of ${ }^{13} \mathrm{C}$ NMR and HRESIMS $(\mathrm{m} /$ $z 625.3515[\mathrm{M}+\mathrm{Na}]^{+}$, calcd for $\left.\mathrm{C}_{38} \mathrm{H}_{50} \mathrm{NaO}_{6} 625.3500\right)$ data. IR spectroscopy suggested the presence of hydroxyl $\left(3456 \mathrm{~cm}^{-1}\right)$, carbonyl $\left(1716 \mathrm{~cm}^{-1}\right)$ and aromatic double bond (1624, $1450 \mathrm{~cm}^{-1}$ ) groups. The NMR data of 1 (Table S1 and S2, ESI $\dagger$ ) indicated the presence of an enolized 1,3-dicarbonyl ether group $\left(\delta_{\mathrm{C}} 193.8, \mathrm{C}-9 ; 116.3, \mathrm{C}-8 ; 172.9, \mathrm{C}-7\right)$, an unconjugated carbonyl carbon $\left(\delta_{\mathrm{C}} 205.0, \mathrm{C}-1\right)$, a methylene $\left(\delta_{\mathrm{C}} 38.8, \mathrm{C}-5\right)$, a methine $\left(\delta_{\mathrm{C}} 43.2, \mathrm{C}-4\right)$, and three quaternary carbons at $\delta_{\mathrm{C}}$ 79.7 (C-2), 60.2 (C-6), and 49.7 (C-3), which suggested that 1 was a polycyclic polyprenylated acylphloroglucinol. ${ }^{7,26,27}$ Besides the above carbons, signals for eight methyls, six methylenes, nine methines and six quaternary carbons were observed. The NMR spectroscopic data of 1 resembled those of 32-epi-hyperforatin 


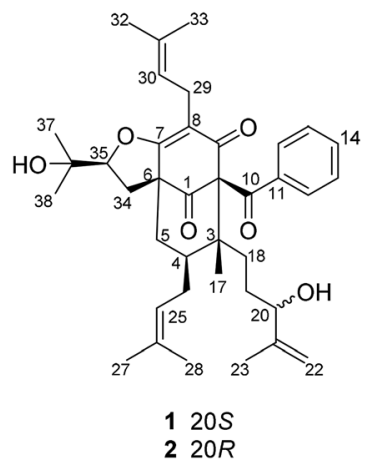

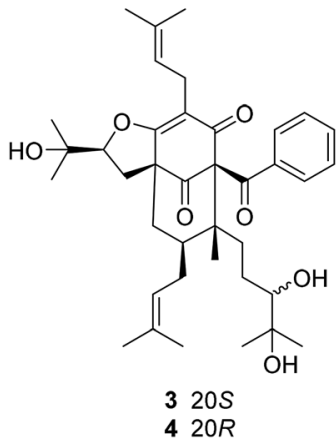

$420 R$

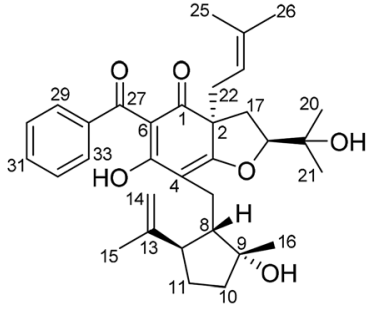

5

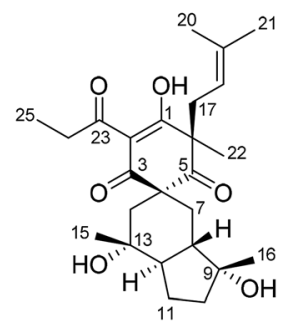

6

Fig. 1 Chemical structures of 1-6.

$\mathrm{E}^{27}$ The main differences were that the absence of the 2-methylpropanoyl group $\left[\delta_{\mathrm{H}} 2.00(\mathrm{CH}), 1.04\left(\mathrm{CH}_{3}\right), 0.96\left(\mathrm{CH}_{3}\right) ; \delta_{\mathrm{C}} 211.5\right.$ $\left.(\mathrm{C}=\mathrm{O}), 43.0(\mathrm{CH}), 21.8\left(\mathrm{CH}_{3}\right), 20.8\left(\mathrm{CH}_{3}\right)\right]$, and the presence of a benzoyl group $\left[\delta_{\mathrm{H}} 7.41(2 \mathrm{CH}), 7.36(\mathrm{CH}), 7.20(2 \mathrm{CH}) ; \delta_{\mathrm{C}} 194.2\right.$ $(\mathrm{C}=\mathrm{O}), 137.1(\mathrm{C}), 132.3(\mathrm{CH}), 128.3(2 \mathrm{CH}), 128.1(2 \mathrm{CH})]$ in 1 (Fig. 1), which implied that the 2-methylpropanoyl group in 32epi-hyperforatin $\mathrm{E}$ was replaced by a benzoyl group in 1 . This was confirmed by the ${ }^{1} \mathrm{H}-{ }^{1} \mathrm{H}$ COSY cross-peaks between $\mathrm{H}-13 / 15$ $\left(\delta_{\mathrm{H}} 7.20\right)$ and $\mathrm{H}-12 / 16\left(\delta_{\mathrm{H}} 7.41\right) / \mathrm{H}-14\left(\delta_{\mathrm{H}} 7.36\right)$, as well as the HMBC cross-peaks from $\mathrm{H}-12 / 16$ to $\mathrm{C}-10\left(\delta_{\mathrm{C}} 194.2\right) / \mathrm{C}-14\left(\delta_{\mathrm{C}}\right.$ 132.3) (Fig. 2). The relative stereochemistry of 1 resembled those of 32-epi-hyperforatin E, basing on the NOESY correlations of Me-17 $\left(\delta_{\mathrm{H}} 1.17\right)$ with $\mathrm{H}-5 \mathrm{~b}\left(\delta_{\mathrm{H}} 1.63\right) / \mathrm{H}-24, \mathrm{H}-5 \mathrm{~b}$ with $\mathrm{H}-34$ and of $\mathrm{H}-5 \mathrm{a}\left(\delta_{\mathrm{H}} 2.10\right)$ with $\mathrm{H}-35\left(\delta_{\mathrm{H}} 4.61\right)$ (Fig. 3). The absolute configuration at C-20 was confirmed by the induced ECD of the in situ formed $\left[\mathrm{Rh}_{2}\left(\mathrm{OCOCF}_{3}\right)_{4}\right]$ complex. ${ }^{28,29}$ According to the bulkiness rule, ${ }^{28-30}$ the $20 S$ configuration of 1 was confirmed by the Cotton effect (positive E band) of the Rh complex (Fig. S1, ESI $\dagger$ ). Additionally, the absolute configuration of $\mathbf{1}$ was unequivocally confirmed by X-ray crystallography (Fig. 4, CCDC 1865373) and ECD calculations (Fig. S2, ESI $\dagger$ ), allowing the assignment of the absolute configuration of 1 as $2 R, 3 R, 4 S, 6 S$,

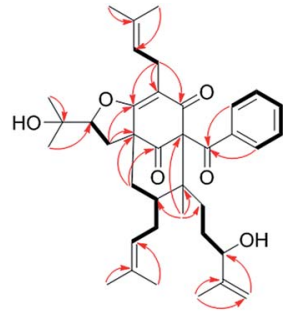

1

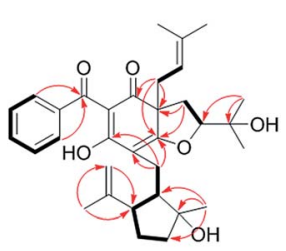

5
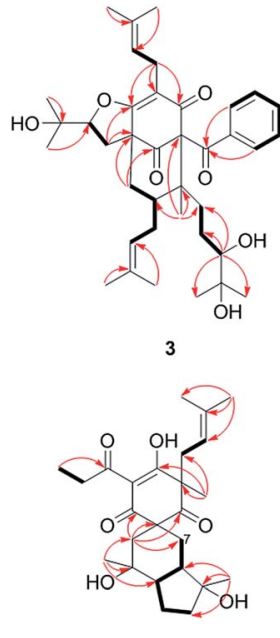

6

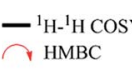

Fig. 2 Key ${ }^{1} \mathrm{H}-{ }^{1} \mathrm{H}$ COSY and $\mathrm{HMBC}$ correlations of 1, 3, 5 and 6.

$20 S, 35 S$ (Fig. 1). Based on the above analysis, the structure of 1 was elucidated and named hyperpatulone A.

Compound 2 was isolated as a colorless oil with $[\alpha]_{\mathrm{D}}^{25}+41.7(c$ 1.0, MeOH). The HRESIMS of compound 2 showed an $[\mathrm{M}+\mathrm{Na}]^{+}$ ion peak at $\mathrm{m} / z 625.3506$ (calcd for $\mathrm{C}_{38} \mathrm{H}_{50} \mathrm{NaO}_{6}, 625.3500$ ), consistent with the molecular formula of $\mathrm{C}_{38} \mathrm{H}_{50} \mathrm{O}_{6}$. Compounds 2 and 1 were separated by using chiral HPLC over a CHIRALPAK IC column. And the NMR spectroscopic data of 2 (Table S1 and S2, ESI $\dagger$ ) was almost identical to those of 1, which indicated that 2 possessed the same planar structure as that of 1. However, compound 2 showed a negative $\mathrm{E}$ band in the in situ $\left[\mathrm{Rh}_{2}\left(\mathrm{OCOCF}_{3}\right)_{4}\right]$ complex-induced ECD spectrum (Fig. S1, ESI $\dagger$ ), which is different from that of 1 , suggesting an $20 R$ configuration in compound 2 . Thus, structure 2 was established, and named hyperpatulone $\mathrm{B}$.

Compound 3 had the molecular formula $\mathrm{C}_{38} \mathrm{H}_{52} \mathrm{O}_{7}$, which was assigned by HRESIMS $\left(\mathrm{m} / \mathrm{z} 643.3640[\mathrm{M}+\mathrm{Na}]^{+}\right.$, calcd for $\mathrm{C}_{38} \mathrm{H}_{52} \mathrm{O}_{7} \mathrm{Na}$, 643.3605). According to its $1 \mathrm{D}$ NMR spectra (Tables $\mathrm{S} 1$ and S2, ESI $\dagger$ ), compound 3 has the same skeleton as that of 1 except for the C-18-C-23 side chain. The differences between them were the absence of a terminal double bond $\left(\delta_{\mathrm{C}}\right.$
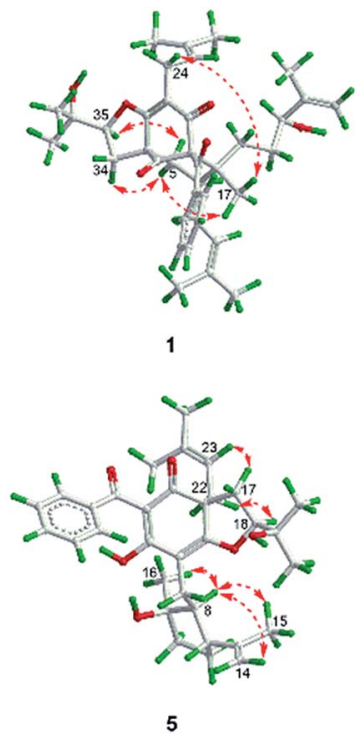

Fig. 3 Key NOESY correlations of 1, 3, 5 and 6. 


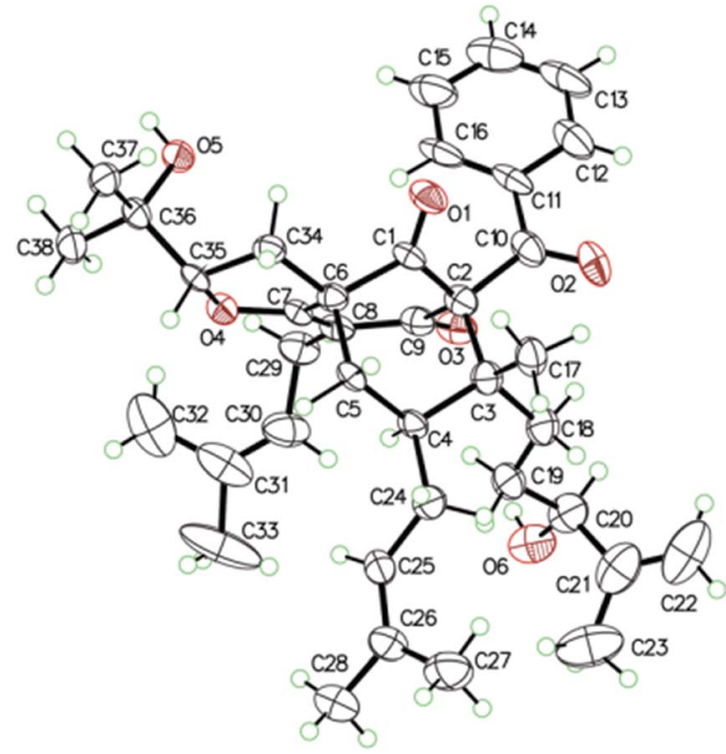

Fig. 4 X-ray ORTEP drawing of 1.

$147.9,111.2$ ) between $\mathrm{C}-21$ and $\mathrm{C}-22$, but the presence of one additional oxygenated quaternary carbon $\left(\delta_{\mathrm{C}}\right.$ 73.1) and one additional methyl group $\left(\delta_{\mathrm{C}} 26.4\right)$ in 3 , and the chemical shifts of C-18, 19, 20, 23 shifted from $\delta_{\mathrm{C}} 32.7,32.0,76.5,17.8$ in 1 to $\delta_{\mathrm{C}}$ $34.2,28.2,79.5,23.8$ in 3 , which indicated the olefinic carbons (C-21, C-22) in 1 were replaced by a tertiary alcohol hydroxy group and a methyl group in 3 . This was confirmed by the HMBC cross-peaks from $\mathrm{H}-20\left(\delta_{\mathrm{H}} 3.26\right) / \mathrm{H}-22\left(\delta_{\mathrm{H}} 1.18\right) / \mathrm{H}-23\left(\delta_{\mathrm{H}}\right.$ 1.12) to C-21 ( $\left.\delta_{\mathrm{C}} 73.1\right)$ (Fig. 2). NOESY correlations of Me-17 $\left(\delta_{\mathrm{H}}\right.$ 1.18) with $\mathrm{H}-5 \mathrm{~b}\left(\delta_{\mathrm{H}} 1.63\right) / \mathrm{H}-24$, of $\mathrm{H}-5 \mathrm{~b}$ with $\mathrm{H}-34$ and of $\mathrm{H}-5 \mathrm{a}$ $\left(\delta_{\mathrm{H}} 2.10\right)$ with $\mathrm{H}-35\left(\delta_{\mathrm{H}} 4.62\right)$ indicated that the relative configuration of 3 was identical to that of 1 (Fig. 3). The in situ $\left[\mathrm{Rh}_{2}\left(\mathrm{OCOCF}_{3}\right)_{4}\right]$ complex-induced ECD spectrum of 3 exhibited a positive $\mathrm{E}$ band for a $20 S$ configuration (Fig. S3, ESI $\dagger$ ). Therefore, structure 3 was determined and named hyperpatulone C.

The molecular formula of 4 was established to be $\mathrm{C}_{33} \mathrm{H}_{42} \mathrm{O}_{6}$ by its HRESIMS $m / z 643.3626[\mathrm{M}+\mathrm{Na}]^{+}$(calcd for $\mathrm{C}_{38} \mathrm{H}_{52} \mathrm{O}_{7} \mathrm{Na}$, 643.3605). The NMR data (Tables S1 and S2, ESI $\dagger$ ) of 4 showed lots of similarities to those of $\mathbf{3}$, suggesting that $\mathbf{4}$ and $\mathbf{3}$ possessed the same planar structure. The only difference between 4 and 3 was the orientation of $\mathrm{H}-20$, which was determined by a negative $\mathrm{E}$ band for a $20 R$ configuration in the in situ $\left[\mathrm{Rh}_{2}\left(\mathrm{OCOCF}_{3}\right)_{4}\right]$ complex-induced ECD spectrum of 4 (Fig. S3, ESI $\dagger$ ). Accordingly, compound 4 was elucidated and named hyperpatulone D.

The molecular formula $\mathrm{C}_{33} \mathrm{H}_{42} \mathrm{O}_{6}$ of compound 5 was assigned by HRESIMS $\left(\mathrm{m} / \mathrm{z} 557.2893[\mathrm{M}+\mathrm{Na}]^{+}\right.$, calcd for $\mathrm{C}_{33} \mathrm{H}_{42} \mathrm{O}_{6} \mathrm{Na}, 557.2874$ ). The $1 \mathrm{D}$ NMR data (Tables $\mathrm{S} 1$ and $\mathrm{S} 3$, ESI $\dagger$ ) of 5 showed lots of similarities to those of hyperascyrone $\mathrm{G},{ }^{18}$ with a $6 / 6 / 5$ tricyclic spiro ring system. The natural occurring polyprenylated spirocyclic acylphloroglucinol derivatives (PSAPs), with a 6/6/5 tricyclic spiro ring system, were a special subgroup of PPAPs. Detailed comparison of the NMR spectra of 5 with those of hyperascyrone $\mathrm{G}$ indicated the absence of a 3- methylbutanoyl group $\left[\delta_{\mathrm{H}} 3.04\right.$ and $2.88\left(\mathrm{CH}_{2}\right), 2.30(\mathrm{CH}), 1.01$ $\left(\mathrm{CH}_{3}\right), 0.98\left(\mathrm{CH}_{3}\right) ; \delta_{\mathrm{C}} 197.6(\mathrm{C}=\mathrm{O}), 45.9\left(\mathrm{CH}_{2}\right), 27.1(\mathrm{CH}), 22.9$ $\left.\left(\mathrm{CH}_{3}\right), 22.6\left(\mathrm{CH}_{3}\right)\right]$ in hyperascyrone $\mathrm{G}$, but the presence of a benzoyl group $\left[\delta_{\mathrm{H}} 7.44(2 \mathrm{CH}), 7.43(\mathrm{CH}), 7.37(2 \mathrm{CH}) ; \delta_{\mathrm{C}} 191.5\right.$ $(\mathrm{C}=\mathrm{O}), 136.6(\mathrm{C}), 131.3(\mathrm{CH}), 128.1(2 \mathrm{CH}), 127.9(2 \mathrm{CH})]$ in 5. Thus, it could be deduced that the 3-methylbutanoyl group in hyperascyrone $\mathrm{G}$ was replaced by a benzoyl group in $\mathbf{5}$. This was confirmed by the ${ }^{1} \mathrm{H}-{ }^{1} \mathrm{H}$ COSY cross-peaks between $\mathrm{H}-30 / 32\left(\delta_{\mathrm{H}}\right.$ 7.37) and $\mathrm{H}-29 / 33\left(\delta_{\mathrm{H}} 7.44\right) / \mathrm{H}-31\left(\delta_{\mathrm{H}} 7.43\right)$, as well as the HMBC cross-peaks from $\mathrm{H}-29 / 33$ to $\mathrm{C}-27\left(\delta_{\mathrm{C}} 191.5\right) / \mathrm{C}-31\left(\delta_{\mathrm{C}} 131.3\right)$ (Fig. 2). The relative configurations of 5 and hyperascyrone $\mathrm{G}$ were very similar by analysis of the NOESY correlations between $\mathrm{H}-18\left(\delta_{\mathrm{H}} 4.55\right)$ and $\mathrm{H}-22 \mathrm{a}\left(\delta_{\mathrm{H}} 2.66\right)$, between $\mathrm{H}-23\left(\delta_{\mathrm{H}} 5.13\right)$ and $\mathrm{H}-17 \mathrm{a}\left(\delta_{\mathrm{H}} 2.15\right)$, between $\mathrm{H}-8\left(\delta_{\mathrm{H}} 1.83\right)$ and Me-15 $\left(\delta_{\mathrm{H}} 1.71\right) / \mathrm{Me}-$ $16\left(\delta_{\mathrm{H}} 1.18\right) / \mathrm{H}-14 \mathrm{a}\left(\delta_{\mathrm{H}} 4.78\right)$ (Fig. 3). The ECD data obtained for 5 showed positive Cotton effects at $\lambda_{\max } 201$ and $278 \mathrm{~nm}$ and a negative Cotton effect at $\lambda_{\max } 242$ and $311 \mathrm{~nm}$ (Fig. S4, ESI $\dagger$ ) comparable to those of hyperascyrone G. ${ }^{18}$ Thus, structure 5 was established, and named hyperpatulone E.

Compound 6 was assigned the molecular formula $\mathrm{C}_{25} \mathrm{H}_{36} \mathrm{O}_{6}$ by HRESIMS $\left(\mathrm{m} / \mathrm{z} 455.2412[\mathrm{M}+\mathrm{Na}]^{+}\right.$, calcd for $\mathrm{C}_{25} \mathrm{H}_{36} \mathrm{O}_{6} \mathrm{Na}$, 455.2404). The 1D NMR data (Tables S1 and S3, ESI $\dagger$ ) of 6 showed lots of similarities to chipericumin D (14)..$^{31}$ Detailed comparison of the NMR spectra of 6 with those of chipericumin $\mathrm{D}$ indicated the absence of a 2-methylbutanoyl group $\left[\delta_{\mathrm{H}} 3.16\right.$ $(\mathrm{CH}), 1.78$ and $1.44\left(\mathrm{CH}_{2}\right), 1.22\left(\mathrm{CH}_{3}\right), 0.83\left(\mathrm{CH}_{3}\right) ; \delta_{\mathrm{C}} 205.1(\mathrm{C}=$ O), $\left.41.9(\mathrm{CH}), 25.3\left(\mathrm{CH}_{2}\right), 19.5\left(\mathrm{CH}_{3}\right), 12.3\left(\mathrm{CH}_{3}\right)\right]$ in chipericumin $\mathrm{D}$, but the presence of a propanoyl group $\left[\delta_{\mathrm{H}} 2.98\left(\mathrm{CH}_{2}\right)\right.$, $\left.0.97\left(\mathrm{CH}_{3}\right) ; \delta_{\mathrm{C}} 201.0(\mathrm{C}=\mathrm{O}), 46.2\left(\mathrm{CH}_{2}\right), 23.0\left(\mathrm{CH}_{3}\right)\right]$ in 6. Thus, it could be deduced that the 2-methylbutanoyl group in chipericumin $\mathrm{D}$ was replaced by a propanoyl group in $\mathbf{6}$. The structure was supported by the ${ }^{1} \mathrm{H}-{ }^{1} \mathrm{H}$ COSY correlations between $\mathrm{H}-24$ $\left(\delta_{\mathrm{H}} 2.98\right)$ and Me-25 $\left(\delta_{\mathrm{H}} 0.97\right)$ together with the HMBC correlations between Me-25 and C-23 ( $\delta_{\mathrm{C}}$ 201.0) (Fig. 2). The relative configuration of 6 was same as that of chipericumin D with the analysis of the NOESY correlations of $\mathrm{H}-7 \mathrm{a}\left(\delta_{\mathrm{H}} 1.91\right) / \mathrm{H}-14 \mathrm{a}\left(\delta_{\mathrm{H}}\right.$ $1.45), \mathrm{H}-12\left(\delta_{\mathrm{H}} 1.78\right) / \mathrm{H}-14 \mathrm{a}, \mathrm{H}-8\left(\delta_{\mathrm{H}} 1.67\right) / \mathrm{Me}-15\left(\delta_{\mathrm{H}} 0.95\right), \mathrm{H}-7 \mathrm{~b}$ $\left(\delta_{\mathrm{H}} 1.76\right) / \mathrm{Me}-16, \mathrm{H}-8 / \mathrm{Me}-16\left(\delta_{\mathrm{H}} 1.40\right), \mathrm{Me}-15 / \mathrm{H}-24\left(\delta_{\mathrm{H}} 2.98\right)$ and $\mathrm{H}-7 \mathrm{~b} / \mathrm{H}-18\left(\delta_{\mathrm{H}} 4.55\right)$ (Fig. 3). In addition, compounds 6 and chipericumin D (14) gave closely correlated Cotton effects in the ECD spectrum (Fig. S4, ESI $\dagger$ ). Thus, structure 6 was established, and named hyperpatulone $\mathrm{F}$.

Ten known compounds were identified as uralodin A (7), ${ }^{32}$ uralodin B (8), ${ }^{13}$ attenuatumione $\mathrm{H}(\mathbf{9}),{ }^{26}$ uralione D (10), ${ }^{7}$ uralione I (11) ${ }^{7}$ tomoeone A $(\mathbf{1 2}),{ }^{15}$ tomoeone B $(\mathbf{1 3}),{ }^{15}$ chipericumin $\mathrm{D}(\mathbf{1 4}),{ }^{31}$ hyperascyrone $\mathrm{F}(\mathbf{1 5}),{ }^{18}$ hypercohone $\mathrm{G}(\mathbf{1 6}),{ }^{33}$ by comparison of their spectroscopic and physical data with those of related literature.

The isolates 1-16 were tested for their cytotoxic activities by MTT assay on human HepG-2, HeLa, MCF-7 and A549 cell lines. Cisplatin was used as the positive control. As shown in Table 1, PSAPs compounds (5-6, 12-16) exhibited more potent cytotoxic activities than other PPAPs compounds (1-4, 7-11), with $\mathrm{IC}_{50}$ values of $9.52 \pm 0.27$ to $42.33 \pm 1.91 \mu \mathrm{M}$. Especially, compound 5 shows significant cytotoxicities toward HepG-2, HeLa and A549 cell lines $\left(\mathrm{IC}_{50}=9.52 \pm 0.27,11.87 \pm 0.22\right.$ and $12.63 \pm 0.12$ $\mu \mathrm{M})$. 
Table 1 Cytotoxic activities of compounds 1-16

\begin{tabular}{lllll}
\hline & \multicolumn{2}{l}{} & \\
\cline { 2 - 3 } Compounds & HepG-2 & HeLa & MCF-7 & \multicolumn{1}{l}{ A549 } \\
\hline $\mathbf{1}$ & $>50$ & $>50$ & $>50$ & $>50$ \\
$\mathbf{1}$ & $>50$ & $>50$ & $46.83 \pm 1.26$ & $>50$ \\
$\mathbf{3}$ & $>50$ & $>50$ & $>50$ & $>50$ \\
$\mathbf{4}$ & $>50$ & $45.79 \pm 1.21$ & $>50$ & $44.35 \pm 0.62$ \\
$\mathbf{5}$ & $9.52 \pm 0.27$ & $11.87 \pm 0.22$ & $20.83 \pm 0.52$ & $12.63 \pm 0.12$ \\
$\mathbf{6}$ & $26.73 \pm 0.23$ & $39.67 \pm 0.27$ & $42.33 \pm 1.91$ & $36.89 \pm 0.81$ \\
$\mathbf{7}$ & $>50$ & $>50$ & $>50$ & $47.82 \pm 1.17$ \\
$\mathbf{8}$ & $41.03 \pm 0.68$ & $39.27 \pm 1.23$ & $35.72 \pm 0.93$ & $42.90 \pm 1.04$ \\
$\mathbf{9}$ & $>50$ & $>50$ & $>50$ & $>50$ \\
$\mathbf{1 0}$ & $>50$ & $42.67 \pm 0.42$ & $39.31 \pm 0.67$ & $41.32 \pm 1.32$ \\
$\mathbf{1 1}$ & $>50$ & $>50$ & $42.97 \pm 1.21$ & $>50$ \\
$\mathbf{1 2}$ & $30.91 \pm 0.25$ & $27.46 \pm 0.37$ & $35.29 \pm 0.82$ & $21.78 \pm 0.57$ \\
$\mathbf{1 3}$ & $35.67 \pm 0.49$ & $29.67 \pm 0.21$ & $31.44 \pm 0.95$ & $32.47 \pm 0.31$ \\
$\mathbf{1 4}$ & $22.83 \pm 0.53$ & $25.59 \pm 0.32$ & $26.92 \pm 0.58$ & $27.41 \pm 0.71$ \\
$\mathbf{1 5}$ & $29.38 \pm 0.28$ & $24.39 \pm 0.28$ & $27.37 \pm 0.53$ & $23.76 \pm 0.17$ \\
$\mathbf{1 6}$ & $19.28 \pm 0.37$ & $28.59 \pm 0.35$ & $22.91 \pm 0.32$ & $17.92 \pm 0.23$ \\
Cisplatin $^{b}$ & $5.9 \pm 0.45$ & $4.7 \pm 0.17$ & $6.7 \pm 0.61$ & $5.1 \pm 0.21$
\end{tabular}

${ }^{a} \mathrm{IC}_{50}$ values of 1-16 were detected by MTT assay after incubation for $48 \mathrm{~h}$; data are expressed as mean $\pm \mathrm{SD} .{ }^{b}$ Positive control.

\section{Experimental}

\section{General experimental procedures}

Optical rotations were obtained on a JASCO P-1020 polarimeter. UV spectra were recorded using a JASCO V-550 UV/VIS spectrophotometer. CD spectra were measured on a JASCO J-810 spectrometer. 1D and 2D NMR spectra were recorded on Bruker AV-500 NMR spectrometers with TMS as an internal standard. HRESIMS analyses were recorded on an Agilent 6210 ESI/TOF mass spectrometer. Column chromatography (CC) was performed with Silica gel (Qingdao Marine Chemical Plant, Qingdao, P. R. China), ODS (50 $\mathrm{m}$, YMC, Kyoto, Japan) and Sephadex LH-20 (Pharmacia Biotech, Uppsala, Sweden). Preparative HPLC was conducted on a Cosmosil $\mathrm{C}_{18}$ preparative column $(5 \mu \mathrm{m}, 20 \times 250 \mathrm{~mm})$ equipped with a G1311C pump and a G1315D photodiode array detector (Agilent Technologies, CA, USA). All chemical reagents were purchased from Tianjin Damao Chemical Company (Tianjin, P. R. China).

\section{Plant material}

The whole plant of Hypericum patulum was collected in Guizhou Province of China, in August of 2016 and authenticated by Zhenqiu Mai, the senior engineer of Guangdong Province. A voucher specimen (no. 20160817) was deposited in the Institute of Traditional Chinese Medicine \& Natural Products, Jinan University, Guangzhou, China.

\section{Extraction and isolation}

The dried and powdered herbs of Hypericum patulum (12 kg) were extracted under reflux with $95 \% \mathrm{EtOH}(30 \mathrm{~L} \times 3)$ at room temperature. The combined ethanol extract was concentrated to afford a residue $(654 \mathrm{~g})$, which was suspended in water $(4 \mathrm{~L})$ and then extracted with petroleum ether $(\mathrm{PE})(4 \mathrm{~L} \times 3)$ and ethyl acetate $($ EtOAc) $(4 \mathrm{~L} \times 3)$. The $\mathrm{PE}$ extract $(217 \mathrm{~g})$ was subjected to silica gel column chromatography, eluting with PE-EtOAc (100: 0 to $0: 1, \mathrm{v} / \mathrm{v})$ to yield seven fractions (Fr. A-F). Fr. C (18.7 g) was further applied to a silica gel CC with PE/ EtOAc (10:1 to $1: 1, \mathrm{v} / \mathrm{v})$ to afford five subfractions (Fr. C1C5). Fr. C2 $(1.5 \mathrm{~g})$ was purified by Sephadex $\mathrm{LH}-20\left(\mathrm{CHCl}_{3} /\right.$ $\mathrm{MeOH}, 2: 1, \mathrm{v} / \mathrm{v}$ ) and further separated by preparative HPLC $\left(\mathrm{MeOH} / \mathrm{H}_{2} \mathrm{O}, 70: 30, \mathrm{v} / \mathrm{v}\right)$ to yield compounds $1(21.2 \mathrm{mg}), 2$ (18.5 mg), 7 (11.7 mg) and 8 (16.9 mg). Fr. C3 (7.5 g) was purified by ODS CC and Sephadex LH-20 to obtain compounds 3 (12.7 mg), 4 (13.9 mg), 9 (19.7 mg), 10 (15.7 mg) and 11 (13.2 $\mathrm{mg}$ ). Fr. D (21.9 g) was applied to ODS CC using a $\mathrm{MeOH} / \mathrm{H}_{2} \mathrm{O}$ gradient (40:60 to $100: 0, \mathrm{v} / \mathrm{v}$ ) to afford five subfractions (Fr. D.1-D.5). Fr. D.3 (3.6 g) was further purified by Sephadex LH$20 \mathrm{CC}\left(\mathrm{CHCl}_{3} / \mathrm{MeOH}, 1: 1, \mathrm{v} / \mathrm{v}\right)$ and preparative HPLC $(\mathrm{MeOH} /$ $\left.\mathrm{H}_{2} \mathrm{O}, 80: 20, \mathrm{v} / \mathrm{v}\right)$ and to yield compounds 5 (9.5 mg), $12(21.3$ $\mathrm{mg}$ ) and 13 (25.1 mg). Fr. D.4 (5.8 g) was separated by preparative HPLC $\left(\mathrm{MeOH} / \mathrm{H}_{2} \mathrm{O}, 80: 20, \mathrm{v} / \mathrm{v}\right)$ to yield compounds 6 (15.8 mg) and $14(11.9 \mathrm{mg})$. Fr. D.5 (4.9 g) was purified by preparative $\mathrm{HPLC}\left(\mathrm{MeOH} / \mathrm{H}_{2} \mathrm{O}, 80: 20, \mathrm{v} / \mathrm{v}\right)$ to achieve compounds 15 (9.2 mg) and 16 (15.2 mg).

Hyperpatulone A (1). Colorless needle crystals (MeOH); mp 116-117 ${ }^{\circ} \mathrm{C}$; $[\alpha]_{\mathrm{D}}^{25}+39.6(c 1.0, \mathrm{MeOH}) ; \mathrm{UV}(\mathrm{MeOH}) \lambda_{\max } 203,250$ and $277 \mathrm{~nm}$; IR (KBr) $\nu_{\max } 3456,2981,2931,1716,1693,1624$, 1450, 1369, $1227 \mathrm{~cm}^{-1} ;{ }^{1} \mathrm{H}$ and ${ }^{13} \mathrm{C}$ NMR spectroscopic data, see Tables S1 and S2 (ESI $\dagger$ ); HRESIMS $m / z 625.3515[\mathrm{M}+\mathrm{Na}]^{+}$(calcd for $\mathrm{C}_{38} \mathrm{H}_{50} \mathrm{NaO}_{6}$ : 625.3500).

X-ray crystallographic analysis of 1 (Table S4, ESI $\dagger$ ). $\mathrm{C}_{38} \mathrm{H}_{50} \mathrm{O}_{6}, M=602.78$, orthorhombic, space group $P 22_{1} 2_{1} 2_{1} ; a=$ 19.2963(4) $\mathrm{A}, b=16.3762(4) \AA, c=11.0039(2) \AA, \alpha=90^{\circ}, \beta=$ $90^{\circ}, \gamma=90^{\circ}, V=3477.23(13) \AA^{3}, T=100.00(10) \mathrm{K}, Z=4, D_{\text {calcd }}=$ $1.151 \mathrm{~g} \mathrm{~m}^{-3}, F(000)=1304.0$. The final $R$ values were $R_{1}=$ $0.0809, w \mathrm{R}_{2}=0.2257$, and the goodness of fit on $F^{2}$ was equal to 1.156. Flack parameter $=0.0(2)$. The crystal data of compound 1 was deposited with the Cambridge Crystallographic Data Centre (CCDC 1865373, http://www.ccdc.cam.ac.uk/). $\dagger$

Hyperpatulone B (2). Colorless oil; $[\alpha]_{\mathrm{D}}^{25}+41.7$ (c 1.0, $\left.\mathrm{MeOH}\right)$; $\mathrm{UV}(\mathrm{MeOH}) \lambda_{\max } 204,248$ and $274 \mathrm{~nm}$; IR (KBr) $\nu_{\max } 3448,2970$, 2924, 1724, 1693, 1620, 1446, 1369, $1227 \mathrm{~cm}^{-1} ;{ }^{1} \mathrm{H}$ and ${ }^{13} \mathrm{C}$ NMR spectroscopic data, see Tables $\mathrm{S} 1$ and S2 (ESI $\dagger$ ); HRESIMS $\mathrm{m} / \mathrm{z}$ $625.3506[\mathrm{M}+\mathrm{Na}]^{+}$(calcd for $\mathrm{C}_{38} \mathrm{H}_{50} \mathrm{NaO}_{6}$ : 625.3500).

Hyperpatulone C (3). Colorless oil; $[\alpha]_{\mathrm{D}}^{25}+56.6$ (c 1.0, $\left.\mathrm{MeOH}\right)$; $\mathrm{UV}(\mathrm{MeOH}) \lambda_{\max } 204,247$ and $274 \mathrm{~nm}$; IR (KBr) $\nu_{\max } 3425,2977$, 2931, 1705, 1600, 1442, 1389, 1273, 1215, $1119 \mathrm{~cm}^{-1} ;{ }^{1} \mathrm{H}$ and ${ }^{13} \mathrm{C}$ NMR spectroscopic data, see Tables S1 and S2 (ESI $\dagger$ ); HRESIMS $m / z 643.3640[\mathrm{M}+\mathrm{Na}]^{+}$(calcd for $\mathrm{C}_{38} \mathrm{H}_{52} \mathrm{O}_{7} \mathrm{Na}$ : 643.3605).

Hyperpatulone D (4). Colorless oil; $[\alpha]_{\mathrm{D}}^{25}+51.8$ ( c 1.0, $\left.\mathrm{MeOH}\right)$; $\mathrm{UV}(\mathrm{MeOH}) \lambda_{\max } 203,248$ and $275 \mathrm{~nm}$; IR (KBr) $\nu_{\max }$ 3413, 2974, 2927, 1709, 1604, 1446, 1381, 1281, 1219, $1122 \mathrm{~cm}^{-1} ;{ }^{1} \mathrm{H}$ and ${ }^{13} \mathrm{C}$ NMR spectroscopic data, see Tables S1 and S2 (ESI $\dagger$ ); HRESIMS $m / z 643.3626[\mathrm{M}+\mathrm{Na}]^{+}$(calcd for $\mathrm{C}_{38} \mathrm{H}_{52} \mathrm{O}_{7} \mathrm{Na}$ : 643.3605).

Hyperpatulone E (5). Colorless oil; $[\alpha]_{\mathrm{D}}^{25}-37.5$ ( $c$ 1.0, $\left.\mathrm{MeOH}\right)$; $\mathrm{UV}(\mathrm{MeOH}) \lambda_{\max } 208,242$ and $353 \mathrm{~nm}$; IR (KBr) $\nu_{\max }$ 3413, 2965, 2927, 2877, 1716, 1612, 1454, 1376, 1269, $1153 \mathrm{~cm}^{-1} ;{ }^{1} \mathrm{H}$ and ${ }^{13} \mathrm{C}$ NMR spectroscopic data, see Tables S1 and S3 (ESI $\dagger$ ); HRESIMS $m / z 557.2893[\mathrm{M}+\mathrm{Na}]^{+}$(calcd for $\mathrm{C}_{33} \mathrm{H}_{42} \mathrm{O}_{6} \mathrm{Na}$ : 557.2874). 
Hyperpatulone F (6). Colorless oil; $[\alpha]_{\mathrm{D}}^{25}+22.8(c$ 1.0, $\mathrm{MeOH})$; $\mathrm{UV}(\mathrm{MeOH}) \lambda_{\max } 203,216,249$ and $279 \mathrm{~nm}$; IR (KBr) $\nu_{\max } 3410$, 2970, 2935, 2877, 1720, 1662, 1612, 1454, 1385, 1319, 1273, 1211, 1153, $1107 \mathrm{~cm}^{-1} ;{ }^{1} \mathrm{H}$ and ${ }^{13} \mathrm{C}$ NMR spectroscopic data, see Tables S1 and S3 (ESI $\dagger$ ); HRESIMS $m / z 455.2412[\mathrm{M}+\mathrm{Na}]^{+}$(calcd for $\mathrm{C}_{25} \mathrm{H}_{36} \mathrm{O}_{6} \mathrm{Na}$, 455.2404).

\section{Cell culture}

Human HepG-2, HeLa, MCF-7, and A549 cells were obtained from the Human Virology Institute of Sun Yat-Sen University. Cells were maintained in RPMI-1640 medium (Gibco, USA) supplemented with $10 \%$ fetal bovine serum (Gibco, USA) and $1 \%$ penicillin/streptomycin at $37{ }^{\circ} \mathrm{C}$ with $5 \% \mathrm{CO}_{2}$ for $24 \mathrm{~h}$.

\section{Cytotoxic assay in vitro}

Four selected human cancer cell lines at the logarithmic phase were seeded in 96-well plates at $5 \times 10^{3}$ cells per well, respectively. After incubating for $24 \mathrm{~h}$, cells were treated with various concentrations of compounds 1-16 and incubated at $37^{\circ} \mathrm{C}$ for $48 \mathrm{~h}$. Then, the medium of each well was removed and $5 \mathrm{mg}$ $\mathrm{mL}^{-1}$ MTT $(30 \mu \mathrm{L})$ was added. After incubating for $4 \mathrm{~h}$, the supernatant of each well was removed and DMSO $(200 \mu \mathrm{L})$ was added to dissolve the formazan produced in the cells. The absorbance was recorded using an enzyme immunoassay reader (Thermo Labsystems Multiskan MK3) at $570 \mathrm{~nm}$. The $\mathrm{IC}_{50}$ was calculated by the Bliss method: inhibitory rate $=[($ absorbance of the test group - absorbance of the blank control)/ (absorbance of the control group-absorbance of the blank control)] $\times 100$.

\section{Conclusions}

In summary, six new PPAPs derivatives, hyperpatulone A-F (16), together with ten known analogs, were obtained from the dried herbs of Hypericum patulum. Their structures were determined by spectroscopic data, X-ray crystallography, ECD spectrum and $\mathrm{Rh}_{2}\left(\mathrm{OCOCF}_{3}\right)_{4}$-induced ECD. Moreover, compounds 1-16 were evaluated for their cytotoxic activities on human HepG-2, HeLa, MCF-7, and A549 cell lines using the MTT assay. Compound 5 shows significant cytotoxicity toward HepG-2, HeLa and A549 cell lines $\left(\mathrm{IC}_{50}=9.52 \pm 0.27,11.87 \pm 0.22\right.$ and $12.63 \pm 0.12 \mu \mathrm{M})$.

\section{Conflicts of interest}

The authors declare no competing financial interest.

\section{Acknowledgements}

This work was supported by grants from the National Natural Science Foundation of China (No. 81803376, 81673319, 81673670), the Science and Technology Planning Project of Guangdong Province (No. 2016A030303011, 2016B030301004), and China Postdoctoral Science Foundation (No. 2017M620405).

\section{Notes and references}

1 Q. L. Wu, S. P. Wang, L. W. Wang, J. S. Yang and P. G. Xiao, Nat. Prod. Res. Dev., 1997, 10, 15-18.

2 H. F. Lv, Q. G. Chu and H. Z. Hu, Chin. Tradit. Herb. Drugs, 2002, 33, 1135-1138.

3 Z. Y. Xiao and Q. Mu, Nat. Prod. Res. Dev., 2007, 19, 344-355.

4 Z. Q. Yin, Y. Wang, D. M. Zhang, W. C. Ye and S. X. Zhao, Chinese Wild Plant Resources, 2004, 23, 6-11.

5 Y. H. Cui and J. Li, J. Northeast Agric. Univ., 2006, 37, 105-110. 6 L. S. Zhang, G. P. Dong and G. M. Liu, J. Chin. Med. Mater., 2009, 32, 224-226.

7 Z. B. Zhou, Z. R. Li, X. B. Wang, J. G. Luo and L. Y. Kong, J. Nat. Prod., 2016, 79, 1231-1240.

8 E. Ernst, J. I. Rand, J. Barnes and C. Stevinson, Eur. J. Clin. Pharmacol., 1998, 54, 589-594.

9 A. Singer, M. Wonnemann and W. E. Müller, J. Pharmacol. Exp. Ther., 1999, 290, 1363-1368.

10 V. Butterweck, F. Petereit, H. Winterhoff and A. Nahrstedt, Planta Med., 1998, 64, 291-294.

11 S. S. Chatterjee, S. K. Bhattacharya, M. Wonnemann, A. Singer and W. E. Muller, Life Sci., 1998, 63, 499-510.

12 D. Albert, I. Zundorf, T. Dingermann, W. E. Muller, D. Steinhilber and O. Werz, Biochem. Pharmacol., 2002, 64, 1767-1775.

13 X. Q. Chen, Y. Li, X. Cheng, K. Wang, J. He, Z. H. Pan, M. M. Li, L. Y. Peng, G. Xu and Q. S. Zhao, Chem. Biodiversity, 2010, 7, 196-204.

14 L. H. Hu and K. Y. Sim, Tetrahedron, 2000, 56, 1379-1386.

15 W. Hashida, N. Tanaka, Y. Kashiwada, M. Sekiya, Y. Ikeshiro and Y. Takaishi, Phytochemistry, 2008, 69, 2225-2230.

16 J. J. Zhang, X. W. Yang, J. Z. Ma, Y. Ye, X. L. Shen and G. Xu, Tetrahedron, 2015, 71, 8315-8319.

17 S. A. T. Fobofou, K. Franke, G. Sanna, A. Porzel, E. Bullita, P. L. Colla and L. A. Wessjohann, Bioorg. Med. Chem., 2015, 23, 6327-6334.

18 H. C. Zhu, C. M. Chen, J. J. Liu, B. Sun, G. Z. Wei, Y. Li, J. W. Zhang, G. M. Yao, Z. W. Luo, Y. B. Xue and Y. H. Zhang, Phytochemistry, 2015, 115, 222-230.

19 T. Naonobu, Y. Yuki, T. Yutaka and K. Yoshiki, Org. Lett., 2016, 18, 5360-5363.

20 H. Jayasariya, A. M. Clark and C. J. D. Mc, J. Nat. Prod., 1991, 54, 1314-1320.

21 S. A. T. Fobofou, C. R. Harmon, A. H. N. Lonfouo, K. Franke, S. M. Wright and L. A. Wessjohann, Phytochemistry, 2016, 124, 108-113.

22 A. K. George, P. Dan, T. John and C. Susan, Biochem. Biophys. Res. Commun., 1990, 172, 149-153.

23 J. Zhao, Z. P. Zhang, H. S. Chen and X. H. Chen, Acta Pharmacol. Sin., 1998, 33, 67-72.

24 W. Gao, W. Z. Hou, J. Zhao, F. Xu, L. Li, F. Xu, H. Sun, J. G. Xing, Y. Peng, X. L. Wang, T. F. Ji and Z. Y. Gu, J. Nat. Prod., 2016, 79, 1538-1547.

25 X. W. Yang, Y. Q. Ding, J. J. Zhang, X. Liu, L. X. Yang, X. N. Li, D. Ferreira, L. A. Walker and G. Xu, Org. Lett., 2014, 16, 24342437. 
26 Z. B. Zhou, Y. M. Zhang, J. G. Luo and L. Y. Kong, Phytochem. Lett., 2016, 15, 215-219.

27 Y. Guo, N. Zhang, C. M. Chen, J. F. Huang, X. N. Li, J. J. Liu, H. C. Zhu, Q. Y. Tong, J. W. Zhang, Z. W. Luo, Y. B. Xue and Y. H. Zhang, J. Nat. Prod., 2017, 80, 1493-1504.

28 J. Frelek and W. J. Szczepek, Tetrahedron, 1999, 10, 15071520.

29 M. Gerards and G. Snatzke, Tetrahedron, 1990, 1, 221-236.
30 L. Liu, H. Gao, X. Chen, X. Cai, L. Yang, L. Guo, X. Yao and Y. Che, Eur. J. Org. Chem., 2010, 17, 3302-3306.

31 S. Abe, N. Tanaka and J. Kobayashi, J. Nat. Prod., 2012, 75, 484-488.

32 N. Guo, X. Q. Chen and Q. S. Zhao, Acta Bot. Yunnanica, 2008, 30, 515-518.

33 J. J. Zhang, X. W. Yang, J. Z. Ma, X. Liu, L. X. Yang, S. C. Yang and G. Xu, Nat. Prod. Bioprospect., 2014, 4, 73-79. 